\title{
Polito et Claro: The Art and Knowledge of Polishing, 1100-1500
}

\section{Marjolijn Bol}

In the sixteenth century, the great mineralogist Georgius Agricola (1494-1555) wrote that "gems can occur in many ways" but "they are never as bright and light-transmitting in the natural state as when polished." 1 The polishing of the surface of a precious stone by making it as smooth as possible is fundamental to the art of the lapidary; only through the successful application of finishing methods can a gem reveal its potential colour and clarity. But despite its importance, we know surprisingly little about the early history of polishing. The reason for this may be that scholarship has focused more on those lapidary techniques that require the wheel. The wheel is an important tool for the art of engraving, a popular and welldeveloped technique in antiquity, and, by the end of the fifteenth century, it was used for the faceting and engraving of diamond and other hard minerals. ${ }^{2}$ Yet, studies into engraving and faceting at the wheel usually do not reveal the art and knowledge required for the entire process of bringing a gem to perfect smoothness. What is more, the most detailed sources on the practice of polishing were written before the fifteenth century, during a time when the wheel was not used in the workshop of the lapidary.

M. Bol (四)

Utrecht University, Utrecht, The Netherlands

(C) The Author(s) 2019

M. Bycroft, S. Dupré (eds.), Gems in the Early Modern World, Europe's

Asian Centuries, https://doi.org/10.1007/978-3-319-96379-2_9 
Fig. 9.1 Golden ring brooch, England (made), ca. 1250-1300, gold set with blue and purple sapphires and a garnet, $2.4 \times 0.4 \mathrm{~cm}$. The Metropolitan Museum of Art, New York, inventory number 2013.453

Indeed, the wheel, even though it greatly speeds up the process, is not a prerequisite for the art of polishing. Late medieval recipes reveal that, instead, gemstones were rubbed onto flat, smooth, fixed plates with various abrasives to shape, smooth, and polish them. This method allowed the lapidary to give his gem a polished, domed top surface, often quite irregular, and typically a flat or hollowed-out base-the so-called cabochon. Figure 9.1 shows a thirteenth-century golden brooch set with precious stones shaped by this method, in this case blue and purple sapphires and a garnet.

When the wheel was re-introduced to the workshop of the lapidary between the late thirteenth and early sixteenth century, the materials and methods explored in the preceding centuries came to form the basis of the new technology. In fact, as I argue in this chapter, the rediscovery of engraving at the wheel since antiquity, and the early modern invention of faceting, were firmly rooted in the premodern art of polishing precious stones on fixed plates.

\section{Why Polish a Precious Stone?}

Since the earliest treatises on mineralogy, precious stones have been characterized by the fact that they are rare, hard, and of beautiful colour; in the West, they are also noted for their clarity, that is, their ability to transmit visible light. ${ }^{3}$ Of these characteristics, rarity alone cannot be influenced by human artifice, but the stone's hardness governs the degree to which the other two characteristics that determine the value of the stone, its colour and clarity, can be brought out. The stone's hardness, in fact, is decisive for the amount of polish a stone can receive: the harder the stone, the smoother it can become and the higher its polish. In order to better understand the 
methods for smoothing gems described in historical sources, I first briefly discuss how the art of polishing influences the interaction of light with a gem to bring out its colour and clarity. The theories set out in the next two paragraphs reflect a more recent understanding of the art of polishing precious stones, but as the laws of nature on which they are based have not changed, they provide insight into the pre- and early modern technical process as well. ${ }^{4}$

A surface that is rough at microscopic level, such as a wool sweater, paper, or, in our case, an unworked stone, scatters the visible light in all directions. This so-called white light causes desaturation of the colour of the stone, and, in the case of a clear stone, reduces the amount of light that could potentially be transmitted through it. A smooth surface, on the other hand, generates a so-called specular reflection. A specular reflection occurs when light reflects off the surface at the same angle as the incident light ray. The human eye perceives this as "gloss." A specular reflection only occurs when materials are perfectly smooth at microscopic level, such as a glass mirror, metals with a high polish, the wet surface of our eyes, and a precious stone that has been polished to smoothness. Because there is less admixture of white light, a smooth surface also allows for the reflection or transmission of purer wavelengths, and, in this way, it brings out the potential colour of a stone. If the internal structure of the mineral allows it, a smooth surface also helps the visible light to more efficiently penetrate the stone, thereby bringing out its potential colour and clarity from within as well.

To successfully shape, smooth, and polish a gem to microscopic smoothness, the lapidary needs to go through several steps in which small amounts of material are removed from the mineral. Each new step requires a finer abrasive agent. In the first step, the precious stone has to be given its final shape and form with a relatively rough and hard abrasive. Second, the surface of the gem needs to be made as smooth as possible by removing the deep scratches left from the previous step, using a finer and sometimes slightly softer abrasive. Finally, when the gem is completely smooth, it can be polished with an even finer and again often softer, paste-like rubbing material. This procedure not only reflects how precious stones are polished today: as we will see, pre- and early modern sources discuss the same steps to explain how precious stones can be brought to perfect smoothness. ${ }^{5}$ Throughout this chapter, I refer to the three stages in the working of precious stones as "shaping," "smoothing," and "polishing," respectively, and, where relevant, I will insert the original Latin or vernacular terms. In Tables 9.1 and 9.2, at the end of this chapter, the reader finds an overview of the wealth of methods and materials mentioned in the sources for shaping, smoothing, and polishing gems. 


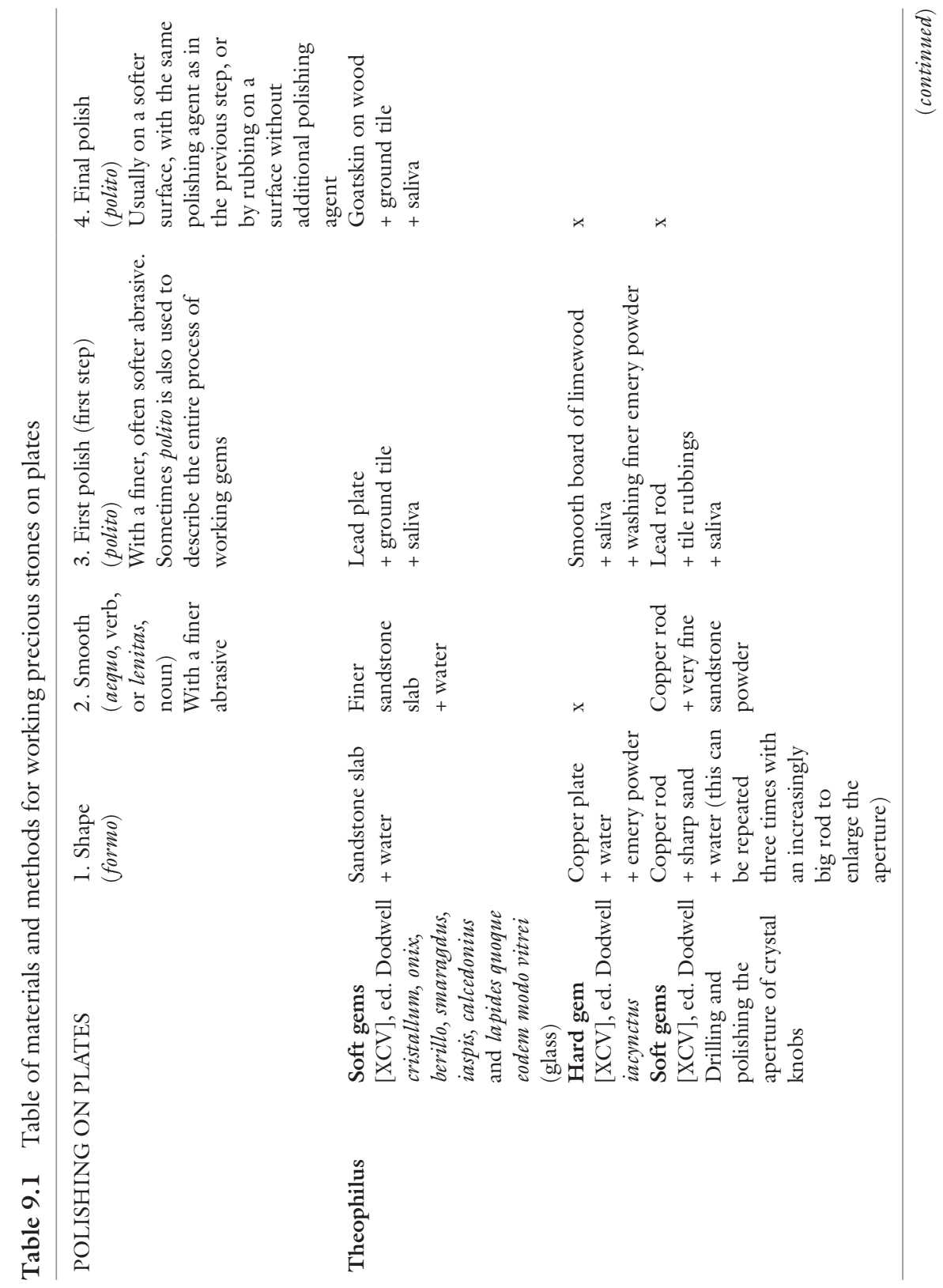




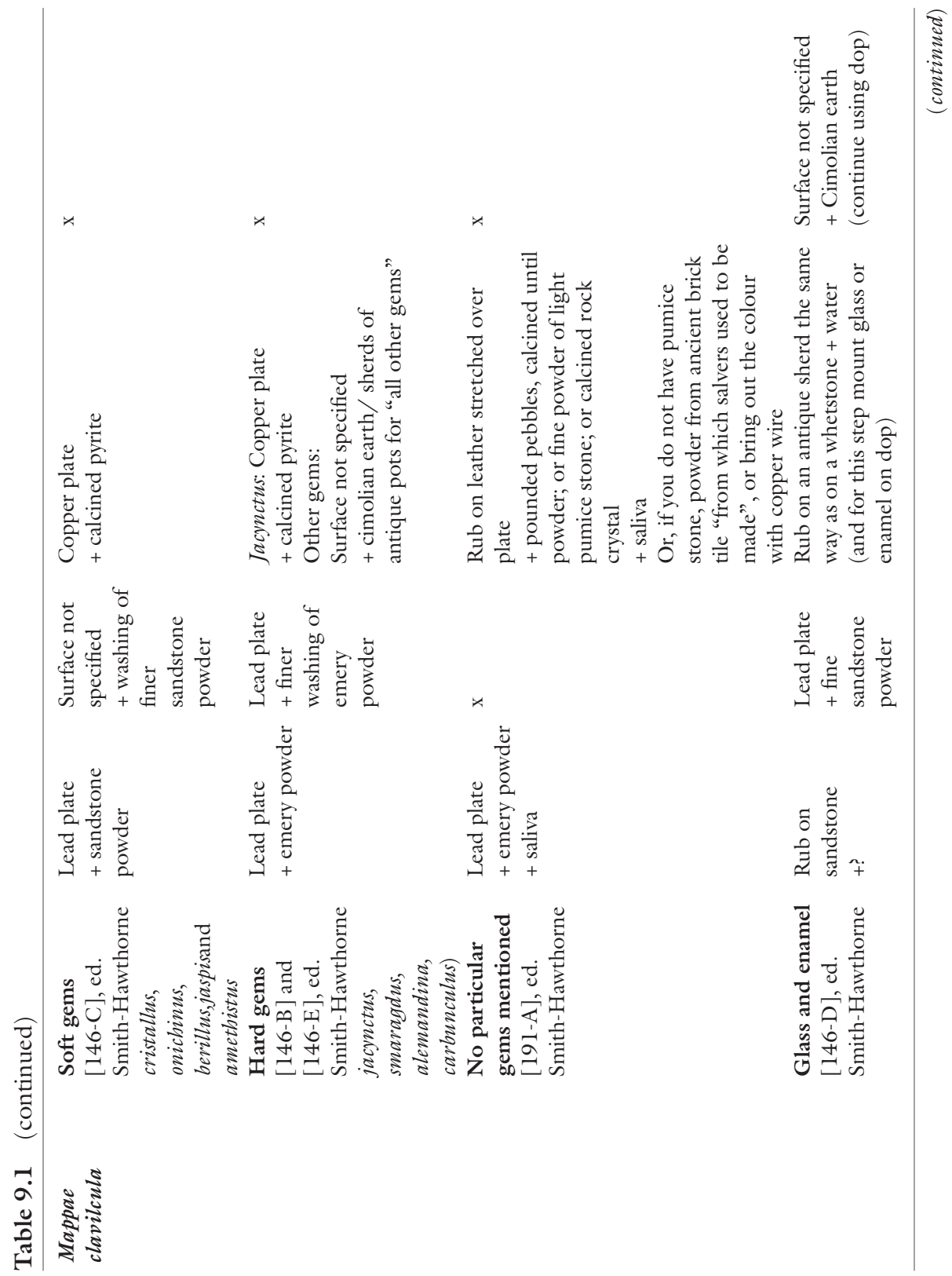




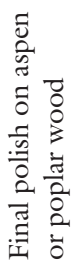

范

蓮

苞.

ฮิ

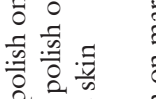

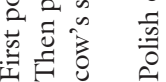

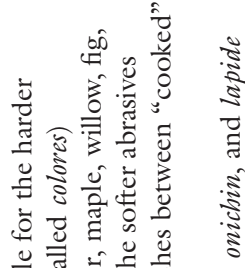

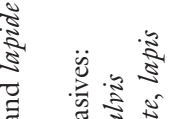

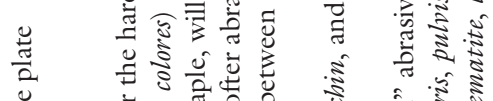

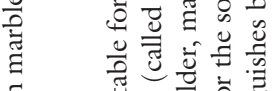

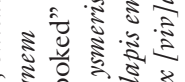

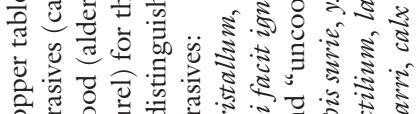

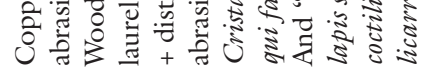

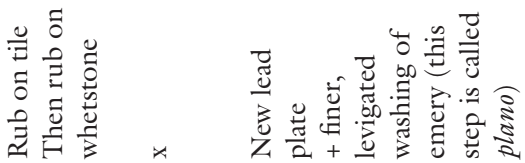

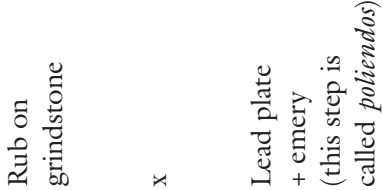

苛

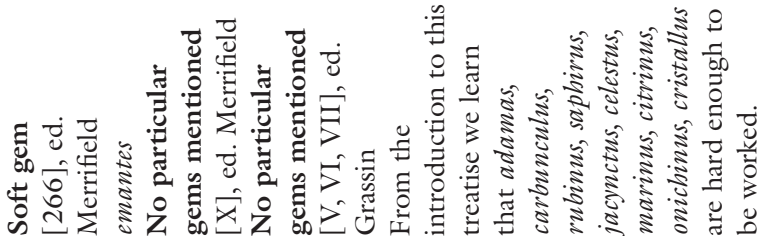

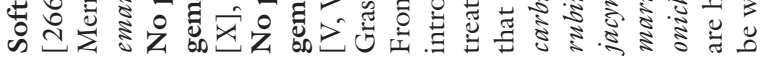

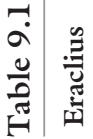

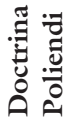


Table 9.2 Table of materials and methods for working precious stones at the wheel

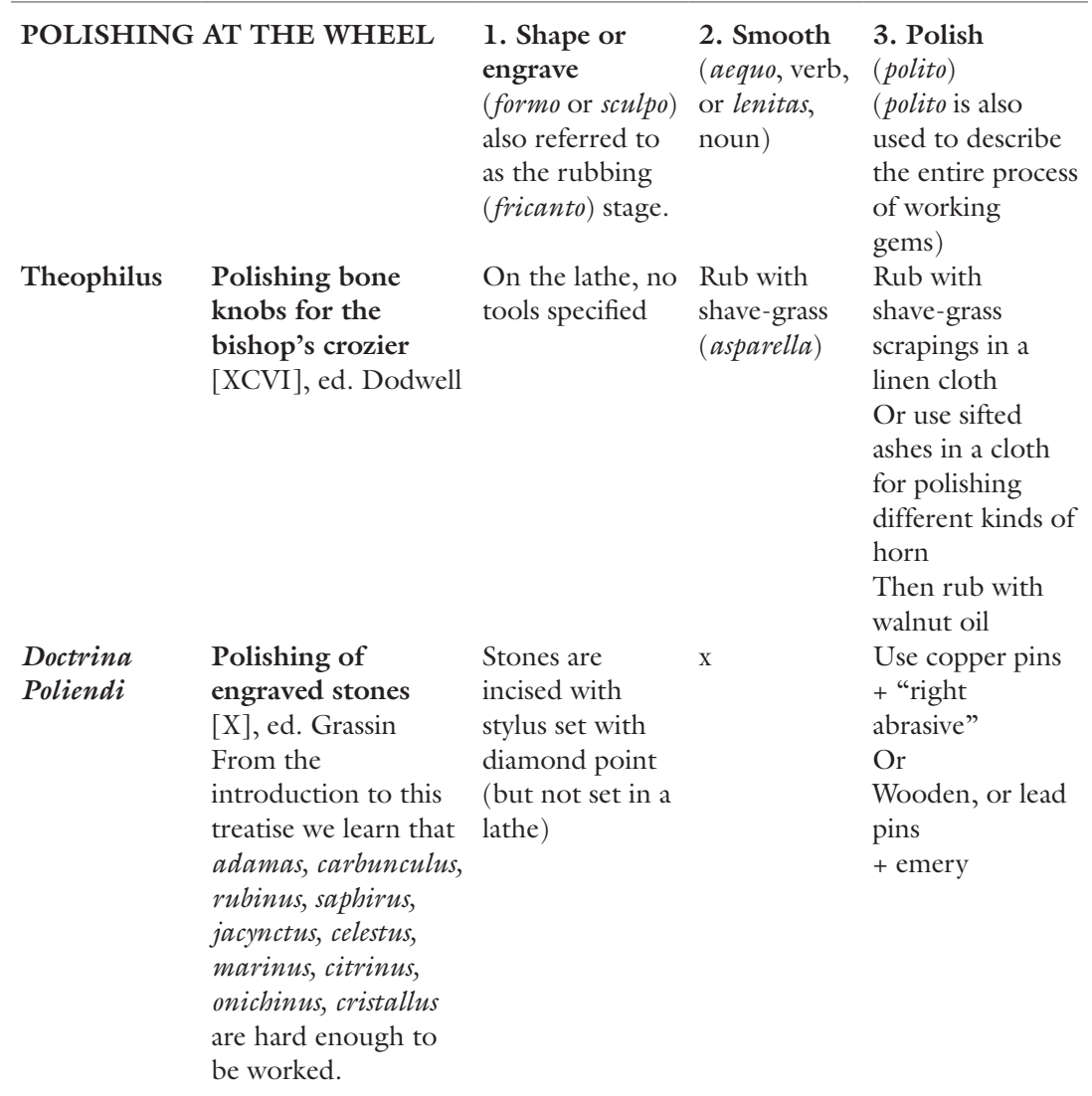


Table 9.2 (continued)

\begin{tabular}{|c|c|c|c|c|}
\hline \multirow[t]{2}{*}{$\begin{array}{l}\text { Peder } \\
\text { Månsson }\end{array}$} & $\begin{array}{l}\text { Polishing of } \\
\text { cabochon or faceted } \\
\text { stones } \\
\text { pp. 142-143, ed. } \\
\text { Johannsen } \\
\text { Does not single out } \\
\text { particular minerals as } \\
\text { hard or soft, but } \\
\text { introductory poem } \\
\text { lists: jaspis, } \\
\text { carbunculus, } \\
\text { ametistus, rubinus, } \\
\text { zaphirus, topasius, } \\
\text { adamas and } \\
\text { turchinus }\end{array}$ & $\begin{array}{l}\text { Shaped on lead } \\
\text { or copper disks } \\
\text { (rotating on } \\
\text { vertical axis) + } \\
\text { emery + water. } \\
\text { Faceted on } \\
\text { lead disk } \\
\text { + emery } \\
\text { The earlier } \\
\text { alternative is } \\
\text { also mentioned: } \\
\text { a fixed } \\
\text { lead plate } \\
\text { + emery powder } \\
\text { + water }\end{array}$ & $\mathrm{x}$ & $\begin{array}{l}\text { Rub on tin disk } \\
+ \text { Tripoli } \\
+ \text { water }\end{array}$ \\
\hline & $\begin{array}{l}\text { Polishing of } \\
\text { engraved stones } \\
\text { pp. 149-150, ed. } \\
\text { Johannsen }\end{array}$ & $\begin{array}{l}\text { Engraved with } \\
\text { small copper } \\
\text { disks } 1-8 \mathrm{~mm} \text { in } \\
\text { diameter, set on } \\
\text { stylus used on } \\
\text { lathe rotating on } \\
\text { horizontal axis. } \\
+ \text { emery powder } \\
+ \text { oil }\end{array}$ & $\mathrm{x}$ & $\begin{array}{l}\text { Hog hair brush } \\
\text { set on stylus } \\
\text { placed in lathe } \\
+ \text { Tripoli }\end{array}$ \\
\hline \multirow[t]{2}{*}{$\begin{array}{l}\text { BnF. Ms. Fr. } \\
640\end{array}$} & $\begin{array}{l}\text { Polishing of } \\
\text { engraved precious } \\
\text { stones } \\
\text { f. } 008 \mathrm{v}\end{array}$ & $\begin{array}{l}\text { Engraved with } \\
\text { diamond point } \\
\text { (no mention of } \\
\text { the lathe) }\end{array}$ & $\mathrm{x}$ & $\begin{array}{l}\text { Brushes } \\
+ \text { Tripoli }\end{array}$ \\
\hline & $\begin{array}{l}\text { Polishing of } \\
\text { precious stones } \\
\text { without engravings } \\
\text { f. } 013 \mathrm{r}\end{array}$ & $\mathrm{x}$ & $\mathrm{x}$ & $\begin{array}{l}\text { On the copper } \\
\text { disk: diamant, le } \\
\text { rubi, saphir and } \\
\text { jacinthe orientale } \\
\text { On the tin disk: } \\
\text { l'esmeraulde, } \\
\text { l'ametiste "and } \\
\text { others" }\end{array}$ \\
\hline
\end{tabular}


Table 9.2 (continued)

\begin{tabular}{|c|c|c|c|c|}
\hline $\begin{array}{l}\text { Georgius } \\
\text { Agricola }\end{array}$ & $\begin{array}{l}\text { Polishing of } \\
\text { cabochon or faceted } \\
\text { stones } \\
\text { p. } 173 \text {, ed. Bandy } \\
\text { and Bandy } \\
\text { Smaragdus, } \\
\text { carbunculus, cyano, } \\
\text { adamanti, crystallo, } \\
\text { jaspidi, beryllo } \\
\text { Polishing of } \\
\text { engraved stones } \\
\text { p. 174, ed. Bandy } \\
\text { and Bandy } \\
\text { Easy to engrave: } \\
\text { Sarda, onyx, } \\
\text { sardonyx, amethystus, } \\
\text { iaspis, molochites, } \\
\text { morion } \\
\text { Difficult to engrave: } \\
\text { Adamas Indicus, } \\
\text { smragdi Scythicus \& } \\
\text { Aegyptius, sapphirus, } \\
\text { cyanus, carbunculus, }\end{array}$ & $\begin{array}{l}\text { For all stones: } \\
\text { Shape on brass } \\
\text { disk } \\
\text { + emery } \\
\text { The diamond } \\
\text { needs to be cut } \\
\text { with diamond } \\
\text { powder } \\
\text { Engraved with } \\
\text { diamond point } \\
\text { placed on the } \\
\text { lathe, or, for } \\
\text { softer gems, } \\
\text { with a fine iron } \\
\text { wire } \\
+ \text { emery powder } \\
\text { + oil } \\
\text { The diamond } \\
\text { needs to cut } \\
\text { with diamond } \\
\text { powder. }\end{array}$ & $\begin{array}{l}\text { Rub on lead } \\
\text { disk } \\
+ \text { Tripoli } \\
\text { earth } \\
\text { Or } \\
\text { Rub on brass } \\
\text { disk } \\
+ \text { powdered } \\
\text { emery } \\
\text { x }\end{array}$ & $\begin{array}{l}\text { Rub on wooden } \\
\text { disk covered with } \\
\text { hide of an elk } \\
\text { "or some equally } \\
\text { thick skin" }\end{array}$ \\
\hline
\end{tabular}

\section{Polishing and Mineral Hardness}

In order to make a precious stone perfectly smooth, the lapidary needs an abrasive that is of the same hardness or harder than the mineral that he or she wants to work. The hardness of a gemstone refers to its ability to resist scratching and abrasion. ${ }^{6}$ The better a mineral can resist scratching and abrasion, the higher it can be polished, and, by extension, the better it will be able to retain its polish. Hardness should be distinguished from toughness, that is, the ability of a mineral to withstand breaking. A diamond, for instance, even though it is the hardest mineral on earth, does not score very high in terms of toughness; its internal structure does not have a high resistance to chipping or breaking. Nephrite jade, on the other hand, although it is not very hard, is the toughest mineral known to man; its resistance to breaking means that it can be carved or engraved exceptionally well, but, because of its softness, it cannot be polished to a high lustre such as that of diamond. ${ }^{7}$ 
Today, there are different methods for determining the hardness of minerals and other materials, but the oldest and best-known is still the scale of Mohs. ${ }^{8}$ Named after the German geologist and mineralogist Friedrich Mohs (1773-1839) who created it in 1812, the Mohs scale is a method of comparing mineral hardness by identifying what minerals can visibly scratch other minerals. The stones are ranked by numerical values from one to ten. The ten numbers represent the ten species of mineral that Mohs examined to establish his scale, the softest being talc (Mohs 1) and the hardest being the diamond (Mohs 10). The scale of Mohs is relative and this means that corundum (Mohs 9), for instance, is twice as hard as topaz (Mohs 8) but that diamond is four times harder than corundum. ${ }^{9}$

Where it helps to better understand the processes mentioned in the sources, I indicate the hardness of the materials mentioned on the scale of Mohs. Unfortunately, we cannot always identify particular minerals with certainty in pre- and early modern sources; terminology and methods of identification were not yet consistent or accurate by modern standards. ${ }^{10}$ Still, an approximation proves helpful in trying to understand the relations between the different polishing materials and methods mentioned. Friedrich Mohs may have been the first to systematize knowledge of mineral hardness, but through the organization of different gemstones in relation to the abrasive method by which they can be brought to smoothness, late medieval and early modern writers on the art of polishing reveal a sophisticated applied know-how about this property of minerals.

\section{Polishing the Softer Gems in the Schedula AND MAPPAE CLAVICULA}

We begin our study with the earliest recipes that tell us how to polish the "softer" precious stones. These can be found in the so-called Mappae clavicula family of recipes and in Theophilus' Schedula diversarum artium. The polishing recipes that belong to the Mappae clavicula tradition survive in manuscripts of which the earliest can be dated to the eighth century CE. A twelfth-century manuscript, kept in the Corning Museum of Glass (Phillipps-Corning manuscript), is of particular interest to us here. ${ }^{11}$ It not only includes the recipes that discuss the techniques of the lapidary from the earlier manuscripts, but also contains a long recipe- $D e$ coloratione musii - that describes the various steps, materials, and tools needed to polish gemstones. ${ }^{12}$ Theophilus' Schedula diversarum artium is 
considered a landmark treatise in the recipe tradition because it organizes its practical instructions for the art of painting, glass painting, and metalwork in three books as an organized whole. There are many manuscripts containing copies of the Schedula, but the two oldest (twelfth century) and most complete are kept in the Herzog-August-Bibliothek in Wolfenbüttel (Ms. 4373) and the Nationalbibliothek in Vienna (Ms. 2527.V). ${ }^{13}$ The recipe for polishing precious stones, however, first appears in a copy of the Schedula dating from the thirteenth century, now kept in the British Library in London (Ms. Harley 3915). ${ }^{14}$

The polishing recipes in the Mappae clavicula and the treatise of Theophilus explain that in order to be able to hold the gem while working it, it first needs to be mounted on a piece of wood. Such holders are still used today and known as a "dop." 15 To make a dop, the Mappae clavicula tells us that one has to take a piece of wood "as thick as the little finger, as long as the width of a palm." 16 At the tip of this stick, one places a mixture of one part of hot pitch (a type of resin) and two parts of tile powder. The precious stone is then pressed against this sticky material so that it can be polished by rubbing it on different surfaces while holding the stick. Theophilus provides us with more information about this substance that he calls tenax (from teneo, "to hold") in an earlier chapter in book three of his treatise. ${ }^{17}$ To make tenax, a brick or tile has to be finely ground and mixed with melted pitch and a little bit of wax. After "stirring it vigorously," it should be poured into water, and, when it is cooling down, "you have to knead it for a long time until you can stretch the composition and draw it out like skin." 18 Theophilus concludes that tenax should be used in a liquid state to cement the gemstone at the end of a wooden stick. ${ }^{19}$

With the stone mounted on the dop thus made, Theophilus uses the example of cristallum (crystal, variety of quartz, Mohs 7) to explain how it should be cut (seco); rubbed (fricanto) into shape (formam); rubbed to make it smooth (aequo); and, finally, rubbed to polish (polito) it. He also uses the term limo (literally: "filing") to distinguish the first stages of shaping and smoothing minerals, where more material is removed from the stone, from the last step of "polishing" (polio) them. ${ }^{20}$ As is demonstrated by the caption of Theophilus' recipe-De poliendis gemmis-he also uses the term "polishing" to refer to the entire process of shaping, smoothing, and polishing a gem. ${ }^{21}$

The polishing process can be summarized as follows. While holding the crystal on the dop-stick, it should first be brought into "shape" (formam) 
by rubbing it "with both hands" (utrisque manibus) against a hard lapidem sabuleum (sandstone, Mohs 6-7) while adding water. ${ }^{22}$ The fact that Theophilus specifies two hands for rubbing the stone suggests that quite a bit of force was involved in shaping the crystal. The function of the water is to reduce the temperature generated from the process of abrasion; too much heat can damage a precious stone. ${ }^{23}$ When the crystal has received its final shape, Theophilus explains that it needs to be made "smooth" (aequum) on another sandstone that is "finer and smoother" (subtilior et aequalior) than the previous. The Mappae clavicula similarly recommends sandstone as an abrasive for the first two steps of shaping and smoothing the softer gemstones. But instead of rubbing them directly on the stone, the Mappae clavicula tells us that precious stones have to be rubbed with the powder of sandstone on a plate of lead (Mohs of pure lead is 1.5). During the second smoothing step, you have to use a finer washing of the same sandstone powder. ${ }^{24}$

The treatise of Eraclius, De coloribus et artibus Romanorum (About the Colours and Arts of the Romans), explains how the lapidary may have set up such lead polishing plates in his workshop. De coloribus consists of 3 books of which the first 2 contain 21 stanzas written in metric verse dating from approximately the tenth century, while the third book is written in prose and dates from the twelfth or thirteenth century. The surviving manuscripts which contain Eraclius' treatise are again all late; one of the oldest, now kept in the British Library (Ms. Egerton $840 \mathrm{~A}$ ), is from the thirteenth century, and a second manuscript, kept in the Bibliothèque nationale de France, Paris (Ms. Lat. 6741), was transcribed in 1431 and contains the only "complete" third book of Eraclius. ${ }^{25}$ Most of the recipes on working precious stones appear in the first book of the treatise, including the instruction on how to set up the plates for polishing. ${ }^{26}$

Eraclius tells us that in order to make a surface for working precious stones, you must take a plate of lead which is held between two wooden boards that are joined by a centre piece of iron "so as to keep the lead steady" (quae firmant undique plumbum). Further stressing the importance of steadying the surface on which the gems are worked, Eraclius clarifies that "the lead alone belongs to the business of cutting, and the outer plates are as guides to make it run round evenly" (nam plumbo soli tribuetur cura secandi. Ipsi custodes laminae sint exteriores, ut sibi dent rectum recto consumere cursum). Carefully describing the function of the abrasive, Eraclius continues that the lead alone is not enough to work a precious stone: 
[...] you would not overcome such great hardness by the unassisted softness of the lead, unless you join to it some powder, such as the pulverized fragment of a furnace [brick], which you will be able to fasten to the tender plate, for this addition will make the lead sharp, and the fragments of the brick also have equal force; you must cut it [the gem] adding to it a little river water. ${ }^{27}$

The pulverized brick Eraclius mentions here, and, as we will see, powder from ceramic tiles and ancient pots, appears to have been commonly used in the final process of polishing a gemstone; when all the deep scratches have been removed, a softer, more clay-like, polishing paste is required. Theophilus, for instance, advises the lapidary to prepare a paste of fine "tile powder" (tegulam humidam) that is rubbed with saliva (saliva) on a "hard whetstone" (cotem duram). The binding properties of saliva helped the lapidary to make a soft, smooth paste of the clay of which the tiles were made. Using the paste of tile powder thus prepared, you can now give the crystal its first polish by rubbing it on a "smooth sheet of lead" (tabulam plumbeam aequalem) until "it takes on a shine" (donec fulgorem accipiat).

The crystal receives its final polish from the same tile rubbings made into a paste with saliva, but this time it is applied to a softer surface of clean goatskin stretched on a wooden frame. On this, you have to "rub" (fricatum) the crystal until "it is completely clear" (omnino lucidum fiat). ${ }^{28}$ As an alternative to tile powder, Theophilus explains that "very fine powder of crystal" (tenuissimus pulvius de fragmentis cristalli) mixed with water can be used to polish gems as well. But in this case, instead of lead or goatskin, a "board of linden wood" (lignum de tilia) should be used as a polishing surface.

Theophilus concludes his instruction on the polishing of crystal with the remark that other gems, such as onix, berillo (possibly a relatively soft green mineral variety), smaragdus (possibly emerald, green variety of beryl, 7.5-8 Mohs), iaspis (possibly jasper, impure variety of quartz, 6-7 Mohs), and calcedonius (possibly variety of chalcedony, 6-7 Mohs) are cut (secantur), rubbed (fricantur), and polished (poliuntur) in the same manner. The Mappae clavicula includes a similar list of precious stones in its recipe for "rubbing gems of a softer nature" (gemmae mollioris naturae fricantur): cristallus, onichinus, jaspis, berillus, and, in addition to Theophilus, amethistus (possibly violet quartz variety, Mohs 7 , but lower when impure). ${ }^{29}$ Whatever the true identity of the gems 
listed here, we can be fairly certain that they were indeed all relatively soft mineral varieties with a Mohs hardness of below or at most around 8. It would have been impossible, or at the very least an extremely lengthy process, to work gemstones harder than this using sandstone as abrasive.

\section{Polishing the Harder Gems in the Schedula AND THE MAPPAE CLAVICULA}

Surviving jewellery shows that the hardest of precious stones were polished during premodern times as well. The thirteenth-century golden ring brooch mentioned earlier, for instance, is set with blue and purple sapphires of the mineral variety corundum (Mohs 9), the hardest mineral before the diamond (Fig. 9.1). Eraclius, in a recipe for "giving clarity to gems"-De gemmis quomodo lucidae funt-correctly observes that "the harder it is [the gem], the brighter polish will it take" (quanto durescit, tanto magis ipsa nitescit). ${ }^{30}$ To learn how the medieval lapidary would have worked these harder mineral varieties, we have to return to the treatise of Theophilus and the Mappae clavicula.

Theophilus singles out the jacynctus (possibly blue or purple variety of corundum, Mohs 9) as a gem harder than all the other precious stones (jacinctus, qui durior est). ${ }^{31}$ The first difference in working the jacinctus lies in the use of a harder abrasive. Theophilus recommends using ismaris, a mineral known today as emery. The Mappae clavicula also explains that the harder gems such as jacinctus, smaragldus, alemandinus (possibly a harder variety of garnet, 7.5-8.5 Mohs), and carbunculus (?) are rubbed with powdered emery stone (ismiri lapide) until they have the desired shape (formam). ${ }^{32}$ Emery, according to the Mappae clavicula, "is rough and invincible, grinding (terens) everything: stones (lapides) and gems (gemmaeque) are filed (limantur) with it." 33

Emery is a non-precious mineral variety of corundum, which, in its purest form, has a hardness of 9 on the scale of Mohs. It is harder than any of the other abrasives Theophilus and the Mappae clavicula mention for the polishing of the softer gems and hard enough to polish all stones except the diamond. The Mappae clavicula tells us that to prepare emery for working precious stones, it needs to be broken into a very fine powder using a hammer on a hard anvil. ${ }^{34}$ The resulting powder should be sprinkled on a lead plate that is fixed to a wooden bench, and, using water, 
"every kind of gemstone may be brought to shape on it" (et in eo qualiscunque gemma formanda est). The emery powder that is used for this first stage of abrasion then needs to be levigated to separate the finer from the coarser particles. The finest particles have to be put on another lead sheet "and any kind of gem stone is rubbed until it is perfectly smooth" (et in eo quaelibet gemma fricatur usque ad lenitatem). Theophilus provides us with similar instructions, but, instead of lead, recommends the harder gems to be shaped on copper (pure copper would have a Mohs hardness of about 3 ). According to Theophilus, emery stone needs to be powdered until it is like "sand" (sabulum) and then, on a sheet of copper, the jacinctus is "shaped" (formatur) with this emery sand mixed with water. The washing that flows from this first rubbing "is carefully gathered in a clean basin and on the following day, when it has stood overnight, the water is all poured away and the powder is dried." 35

When a hard mineral is worked with emery, the emery sand not only abrades the precious stone but the emery particles become increasingly fine as well. The carefully levigated washing of emery that Theophilus and the Mappae clavicula advise you to collect would have included these finer particles. Levigation is a crucial step in the lapidary process; if the abrasive is not made increasingly fine during each new step of bringing a mineral to smoothness, the larger emery particles would keep scratching the gemstone. For the same reason, it is significant that the Mappae clavicula teaches us to switch the lead plates when the finer grade of emery is used. The larger particles of the first smoothing session would have been embedded in the lead plate and thus would have scratched the stone during the second smoothing step.

Unlike the Mappae clavicula, Theophilus goes directly from shaping to polishing when he explains how to work the harder gems, thus omitting the intermediary smoothing step that he did recommend for working the softer gems. We learn that to "give the jacinctus its final polish" (atque desuper jacinctus poliatur), the levigated emery powder is mixed into a soft paste with saliva. Similar to the powdered crystal, this paste of emery powder is applied to a "smooth linden board" (tabulam aequalem detilia). In the Mappae clavicula, the jacynctus is given its final polish with the powder of calcined lapidis igniarii (pyrite, Mohs 6-6.5) on a sheet of copper. ${ }^{36}$ For more information about the nature and use of these different polishing agents and their surfaces, we have to turn to a thirteenth-century treatise known as the Doctrina poliendi. 


\section{The “Biting” Colours in the Doctrina POliendi}

The anonymous Doctrina poliendi, planandi et perforandi pretioses lapides stands out for being the first recipe treatise to be entirely dedicated to the art of the lapidary. The Doctrina poliendi exists in two thirteenth-century copies: the first copy is written in Latin and kept in the British Library (Ms. Add. 41 486) and the second, written in old French, can be found in the Bibliotèque nationale de France, Paris (Ms. Lat. 7400 A). ${ }^{37}$ Unlike the Mappae clavicula and the treatise of Theophilus, the Doctrina poliendi does not distinguish between the different methods used for polishing precious stones of the harder and softer mineral varieties. Instead, it provides us with a more general list of the gems that are hard enough to be worked. We learn that some gemstones are harder than others, and that the Doctrina poliendi is a "treatise on the harder stones, as they are nobler" (ideo tamquam de dignioribus duriorum premitto tractatum). ${ }^{38}$ The stones that are worked, so we read, include the adamas (diamond, Mohs 10 or maybe variety of corundum, Mohs 9), carbunculus (?), rubinus (red variety of corundum, Mohs 9), saphirus (blue variety of corundum, Mohs 9), jacynctus (coloured variety of corundum, Mohs 9), celestus (?), marinus (?), citrinus (yellow variety of corundum), onichinus (black variety of chalcedony, Mohs 6-7), and crystallus (rock crystal, variety of quartz, Mohs 7). ${ }^{39}$

The Doctrina poliendi mentions similar materials and methods as the previous recipes we discussed, but uses a different terminology to describe them. After the stone has been sawed to size, it can be "polished" (poliendos) on a plate of lead dressed with emery. ${ }^{40}$ In the previous treatises, this first stage in the lapidary process would not have been called the polishing, but the "shaping" (formo) stage. The Doctrina calls the smoothing stage ad planandos lapides (aequo in Theophilus) and this is done, as in the earlier works, on a new plate of lead with a washing of levigated emery sand filtered through a linen cloth. The final polishing stage then is called "colouring" (coloro) and the polishing agents, appropriately, are called "colours" (colorem).${ }^{41}$ We learn that you have to make a harder and more "biting colour" (mordaciorem colorem) for "the hardest of stones" (lapidibus durioribus duriorem). These "biting colours" (coloribus mordentibus) can be used to polish the harder stones on the "copper table" (tabulam eneam) that, as we have seen, the Mappae clavicula similarly mentioned for the polishing of the harder jacinctus. The "soft colours" (molioribus coloribus) in their turn, are used to polish the softer stones on a wooden table of alnos (alder), acero (maple), salicis (willow), ficus (fig), lauri (laurel), "or a similar species." 42 
The Doctrina poliendi then continues to set out how the different colours, or polishing agents, have to be prepared. Some are prepared "raw," while others must be "cooked" on the fire. Examples of the first are lapis surie (Syria stone?), ysmeris (emery), pulvis coctilium (brick powder), lapis ematite (hematite, Mohs 5-6), lapis licarri (litharge, Mohs 2), calx [viv]a (quicklime, 2-3 Mohs), "and the like." ${ }^{3}$ The abrasives that are "cooked" before use are all of the harder mineral varieties and include cristallum, onichin, and lapide qui facit ignem (pyrite). ${ }^{44}$ The Doctrina poliendi also tells us how these calcined abrasives have to be ground. Using the example of cristallum, we learn that after it has been burned, it has to be "crushed heavily on porphyry similar to the colours of which the paintings are made" (fortiter super marmor porfiticis sicut teruntur colores de quibunt picture fiunt). ${ }^{45}$ The concern of the painter with the particle size of his pigments is indeed very similar to the concern of the lapidary with the particle size of his abrasives. The fifteenth-century recipe treatise on the art of painting by Cennino Cennini (c. 1360-before 1427), for instance, talks about the qualities of the different kinds of grinding slabs the painter can use. Cennini explains that to grind your colours you have to use proferitica rossa (red porphyry, 6-7 Mohs). He continues that there are various other slabs for grinding colours such as serpentino (serpentine, variable between Mohs 3-6) and marmo (Marble, Mohs 3), but that:

[...] Serpentine is a soft stone and is not good; marble is still worse, for it is too soft. But porphyry is the best of all; and it will be better if you get one of those which are not so very much polished (puliti) [..]. ${ }^{46}$

\section{Early Rotary Technologies and the Art of Polishing Engraved Gemstones}

Even though rotary technology was known and used during the time of Theophilus and the Mappae clavicula, the Doctrina poliendi is the first treatise to discuss it for working precious stones. ${ }^{47}$ It explains that to "pierce" (perforantur) precious stones, they are worked with a "stylus" (stili) made from "iron" (ferrum) that has an adamantem (possibly diamond, or variety of corundum) inlaid in its head. ${ }^{48}$ With this tool, you pierce the gem using the "iron lathe" (ferreotorno) or a "drill" (trapano). You use another stylus, this time "red copper" (ère rubeo) dressed with emery mixed with water, to enlarge the aperture of the hole. This stylus is mounted on the lathe or used with a drill as well. ${ }^{49}$ The Doctrina poliendi mentions a similar method to "cut" ( secandos) stones to the right size.$^{50}$ In this last recipe, the 
author gives a glimpse of the duration of the process of cutting with the help of rotary movement when he tells us that one should "move for a long time with the help of water and the lathe" (et diu movendo cum aqua seca et cum torna). ${ }^{51}$

Finally, the Doctrina poliendi also discusses the use of rotary technology for the polishing of engraved precious stones. The engraving itself, however, is still done manually. To "engrave gemstones" (ad sculpendos lapides), we learn that you have to set an adamantem in an iron stylus in the "same way it would be set in a ring" (acutum sicut includitur lapis in anulo). ${ }^{52}$ We learn that when you want to "polish" (colorabis) this "engraving" (sculpturas), you use a "lathe with a brass stylus" (torno et rotulis eneis) dressed with the "right" polishing agent. ${ }^{53}$ The author continues that, if you wish, you can also polish with a wooden stylus, or use a lead stylus with emery. Hence, the Doctrina's polishing styli are made from the same materials as the fixed plates it recommends for the shaping, smoothing, and polishing of precious stones without engravings. This suggests that at the time the Doctrina poliendi was written, the use of rotary technology was still reserved for the piercing and cutting of gems and the polishing of incised stones.

\section{Engraving and Polishing at the Wheel}

If its use was still limited in the thirteenth century, the wheel eventually became the lapidary's most important tool in the course of the fifteenth and sixteenth centuries. At this time, rotary technologies were used for all lapidary techniques, including that of engraving precious stones and the newly invented art of faceting. Georgius Agricola, for instance, mentions the use of a diamond point set on a lathe to engrave the hardest of gems. He even includes a list of stones that are hard enough to be engraved by this method: the Indian adamas (diamond, Mohs 10), the Scythian and Egyptian smaragdus, sapphirus (?), cyanus (blue variety of corundum, Mohs 9), and the carbunculus (red variety of corundum, Mohs $9^{54}$ ). Agricola explains that to engrave these hard gemstones, a diamond point should be set in iron. This iron stylus is "set in a square hole in a brass shaft" around which a "heavy cord" goes. This cord then goes down around a wheel so that figures can be engraved on the gem:

The engraver, turning the wheel with the right hand and at the same time rotating the shaft, applies the gem set in pitch [on the dop] to the diamond point with the left hand $[\ldots]^{55}$ 
For engraving the softer precious stones, which include sarda (variety of chalcedony, Mohs 6-7), onyx, sardonyx (variety of chalcedony, Mohs 6,5-7), amethystus, jaspis, molochites (malachite, Mohs 3,5-4), and morion (dark quartz variety, Mohs 7), Agricola recommends using a variety of iron wires of different size and sharpness, coated with oil and emery powder. He writes that this is fast and flexible because "it costs the engraver little to use emery: a considerable sum to use diamond." ${ }^{56}$

A landmark treatise on the art of working precious stones at the wheel is a work copied between the second and third decade of the sixteenth century by the monk Peder Månsson (d. 1534). ${ }^{57}$ After the founder of his order decided that knowledge should be made accessible to the common people, Peder Månsson started to collect foreign works on the practical arts and translated many of them to Swedish. ${ }^{58}$ The works he collected range from the art of navigating the sea and the art of war to the art of farming, weather prediction, a book of artistic recipes, a mineralogical treatise, and, indeed, a book dedicated to the art of the lapidary Konst grafwa stena (The Art of Engraving Stones), now kept in the Kungliga biblioteket of Sweden, Stockholm (Cod. B., f. 187r-f. 198r.). ${ }^{59}$ Whereas the source of Månsson's mineralogical treatise has been identified as Camillo Leonardi's (1450-1550) Speculum lapidum (Mirror of Stones, 1502), the source of his book on the art of working precious stones is unknown. ${ }^{60}$ Its contents suggest that Månsson may have copied it from a late fifteenth- or early sixteenth-century treatise, possibly composed in Italy. ${ }^{61}$ As such, it reflects the state of the art of the lapidary at least several decades before Agricola published his De natura fossilium (1546).

Much of the text of Månsson's treatise is devoted to detailed explanations of how to set up three different rotary tools for working precious stones - tools that, remarkably, he also illustrates with drawings. ${ }^{62}$ Månsson describes a machine for the "sawing of gems" (saagha stenana), he describes a lathe with an axis rotating vertically for the "shaping and polishing of gems" (formera oc slätta stenana, Fig. 9.2), and, finally, a lathe with an axis rotating horizontally that is used for "for engraving a picture in a gemstone" (graffwa beläty äller annath $j$ stena) and for polishing (skinande) these engraved gemstones (Fig. 9.3).

Månsson's lapidary machines are different from the rotary tools used in the late medieval period. Unlike the earlier lathes, which were driven by reciprocal rotary motion (back and forth), Månsson's wheels are driven by a crank with a connecting rod, resulting in continuous rotary 


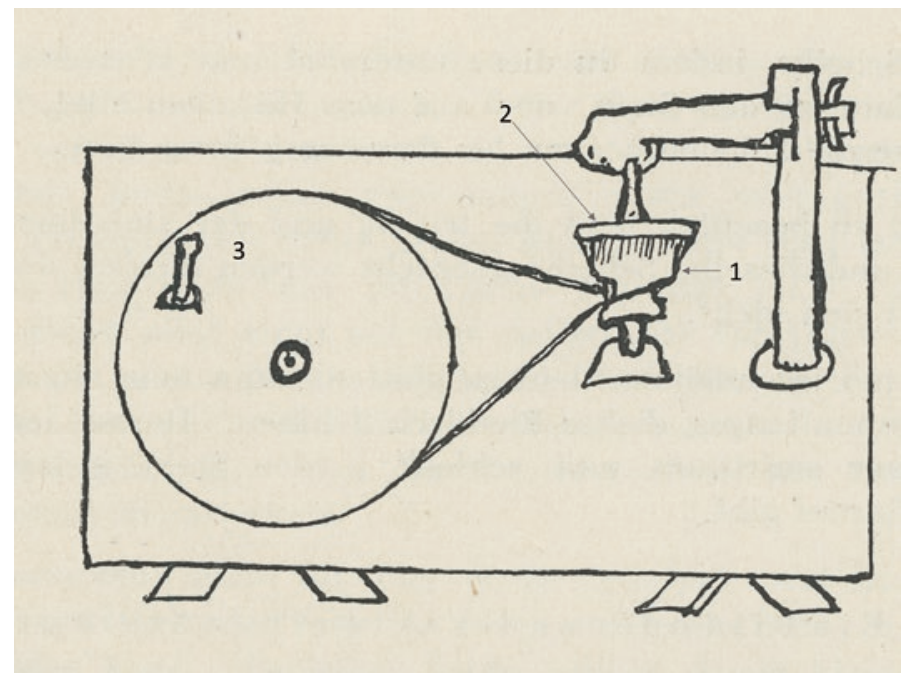

Fig. 9.2 Drawing of a polishing machine, by Peder Månsson. Key: 1 = rotating wooden spindle on top of which the polishing takes place; 2 = flat disks of tin, lead, or copper, mounted on the spindle-the stones are polished on top of these disks; $3=$ crank and horizontal wheel for rotating the spindle. Copied from the original manuscript and published in: Peder Månssons skrifter på svenska, ed. Robert Geete (Stockholm: P. A. Norstedt \& Söner, 1913-1915), 506 and Schriften ïber technische Chemie und Hüttenwesen, ed. Otto Johannsen (Berlin: VDI-Verlag, 1941), 506. Numbering and arrows added by present author

motion (Figs. 9.2 and 9.3). ${ }^{63}$ Continuous rotary motion, which was a discovery of the fifteenth century, is much faster than reciprocal rotary motion because there is no stop-and-start. As a result of its continuous speed, this technology opened up many new opportunities for the lapidary, especially for working the hardest mineral varieties.

Månsson tells us that without smirillus (emery), "you cannot perform the art of the lapidary" (oc wtan honom kan jngen brwka tessa konstena). So, before you can start working, emery has to be finely ground on a plate of polfirio (porphyry), much as the author of the Doctrina poliendi advised as well. We learn that to engrave stones, the emery powder must be completely smooth, but that for shaping and smoothing it need not be so fine. ${ }^{64}$ To engrave images in precious stones, you have to make small, thin copper disks of different sizes. Månsson drew six small circular disks 


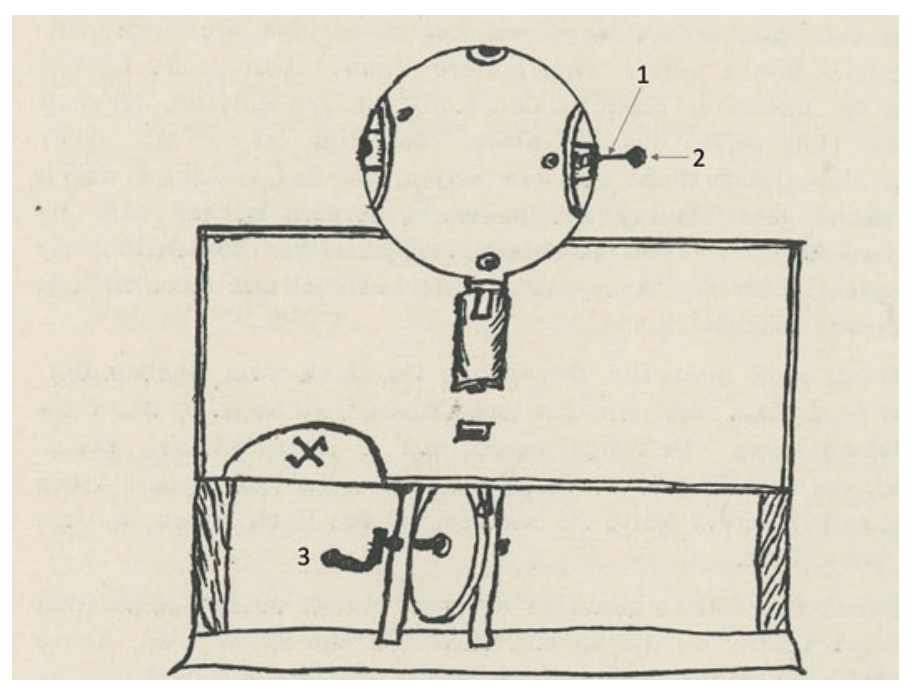

Fig. 9.3 Drawing of an engraving machine, by Peder Månsson. Key: l = rotating stylus; 2 = copper disk attached to the stylus - the stone is engraved against the perimeter, that is, the sharp edge, of the disk; $3=$ crank and vertical wheel for rotating the stylus. Copied from the original manuscript and published in: Peder Månssons skrifter på svenska, ed. Robert Geete (Stockholm: P. A. Norstedt \& Söner, 1913-1915), 506 and Schriften über technische Chemie und Hüttenwesen, ed. Otto Johannsen (Berlin: VDI-Verlag, 1941), 509. Numbering and arrows added by present author

in his manuscript to explain that none of the disks should be bigger than the biggest disk he illustrated, which is $8 \mathrm{~mm}$ (See Fig. 9.4, the smallest disk is $1 \mathrm{~mm}) .{ }^{65}$

These copper disks are attached to iron styli that have a square end made to fit the lathe. Such a stylus (Fig. 9.3) can be placed in the square hole of the brass shaft of the engraving machine so that it can be turned. ${ }^{66}$ The gemstone can now be engraved by pressing it against the sharp, outer side of the tiny, rotating copper disk (Fig. 9.4), not against its flat side as in the polishing machine (Fig. 9.2). Similar to Agricola's wire for the engraving of the softer gems, the disks have to be charged with emery mixed with oil. Månsson tells us that in case you make a mistake during the engraving process, it is important to correct this before the stone is polished. Why this is the case, we learn from a recipe contained in 


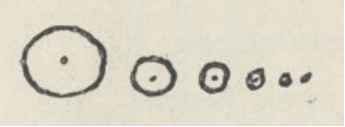

Fig. 9.4 Drawing of six engraving disks by Peder Månsson, true to size. Copied from the original manuscript and printed in Peder Månssons skrifter på svenska, ed. Robert Geete (Stockholm: P. A. Norstedt \& Söner, 1913-1915), 506 and Schriften über technische Chemie und Hüttenwesen, ed. Otto Johannsen (Berlin: VDI-Verlag, 1941), 510

a sixteenth-century manuscript kept in the Bibliotèque nationale de France, Paris (Ms. Fr. 640).

Ms. Fr. 640 contains various scattered, but pertinent remarks about working precious stones at the wheel. The author of the manuscript is unknown, but the treatise stands out for the practical nature of many of the practices it describes, with which, rather remarkably, the author often seems to have experimented himself. ${ }^{67}$ The author of Ms. Fr. 640 explains that before engraving, you have to "roughen" (despolir) the surface of the stone on a "lead wheel" (la roue de plomb). The reason is that too smooth a surface is not suitable for carving images in a precious stone because "the polishing is like varnish or glass (le poliment qui est comme vernis au verre) and this stops the diamant or saphir from engraving (graver) well." 68

Ms. Fr. 640 also tells us how, after you are done engraving, the incised gems ought to be polished. We learn that engraved gems should not be "polished on a copper wheel, but with brushes and tripoli" (Les pierres eai gravées ne se polissent pas sur la roue de cuivre, ains avecq les broisses et le tripoly). ${ }^{69}$ This is because, on the copper wheel, so the author of Ms. Fr. 640 continues, "faceted and flat [perhaps en cabochon?] stones are polished" (pierres taillées à faces et à plain sepolissent). ${ }^{70}$ We do not learn whether the brushes used for polishing engraved precious stones ought to be used on the lathe as well, which, as we have seen, was how the polishing styli mentioned in the Doctrina poliendi were used. ${ }^{71}$ But that this was likely the case for the brushes as well, becomes clear when we return to Månsson who similarly mentions the use of tripoli, an extremely fine, microcrystalline variety of quartz (Mohs 7), for polishing engraved gems with brushes. 
Månsson explains that for the polishing of engraved stones you have to make a brush from hog's hair (swina börstom), "as long and thick as the outer member of your finger" (swaa langth som ytherste lidhen oc tiokth aff enom fingher). ${ }^{72}$ The hairs are bound together with a wire and cut on both ends. This brush is mounted on a stylus and laid in water for a while so that (through the expansion of the hairs) it sits steady. ${ }^{73}$ The stylus is then placed in the axis of the engraving lathe and rubbed with tripolo. Then, while rotating your machine, you hold the engraved gem against the end of the brush to polish it. As would have been the case with the wood and metal styli from the Doctrina poliendi, the hog's hair brush ensures that the polishing agent penetrates into the relief of the engravings so as to make them perfectly smooth. The continuous speed of Månsson's machines allowed the lapidary to engrave his gems with an amazing amount of detail, an art that flourished in Italy especially. There are many examples demonstrating the detail of these sixteenth-century engraved gems, but here it will suffice to show a rock crystal intaglio made around 1531-1535 by the famous gem engraver Giovanni Bernardi di Castel Bolognese (1494-1553, Fig. 9.5). ${ }^{74}$ The crystal medallion, which, as its

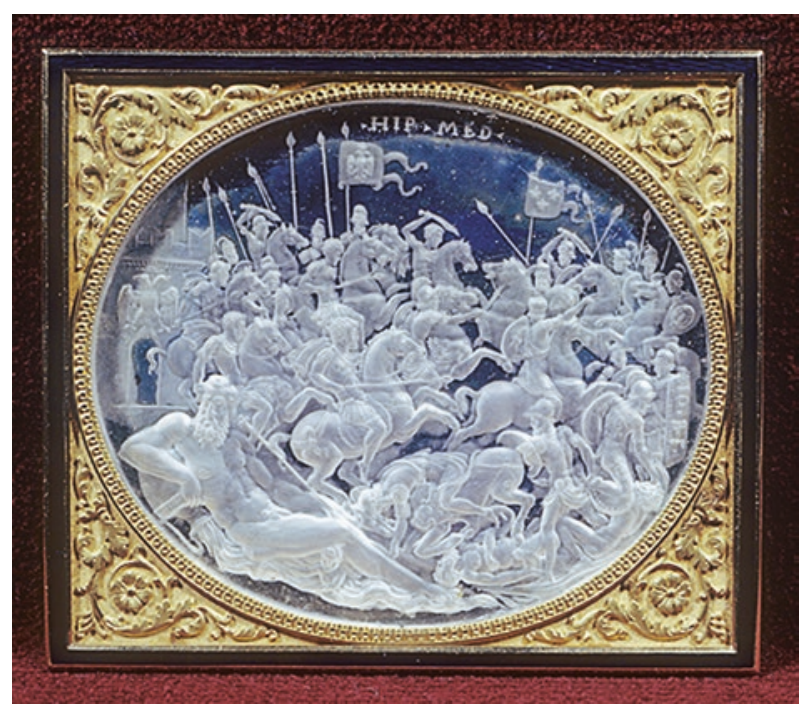

Fig. 9.5 Giovanni Bernardi di Castel Bolognese (1494-1553), The battle of Pavia (engraved at top centre: .HIP.MED.) ca. 1531-1535, rock crystal intaglio, $6.2 \times 7.3 \mathrm{~cm}$. The Walters Art Museum, Baltimore, inventory number 41.68 
inscription shows, was commissioned by Cardinal Ippolito de' Medici (1511-1535), depicts the Battle of Pavia in the fine detail enabled by the speed of continuous rotary motion.

\section{From the Whetstone to the Wheel}

From the sixteenth century onwards, the treatises that mention methods of engraving and the polishing of engraved stones at the wheel also discuss how to polish gemstones at the wheel that are not carved. But for this, as we have seen Ms. Fr. 640 suggested, another type of wheel was used which Månsson discusses in detail as well. According to Månsson, precious stones are shaped, smoothed, and polished on the flat side of rotating disks made from lead (blyskiffwor), tin (then skiffwor), or copper (kopar skiffwor), each attached to their own "spindle" (tridzorna) (Fig. 9.2). These disks are made to turn on a vertical axis, not a horizontal axis such as was used in the engraving machine (Fig. 9.3). Månsson observes that besides being shaped en cabochon, precious stones now receive many different kinds of shapes; the disk made from lead is used to shape gemstones with "facets" (kanther), "cones" (slindor), "rounds" (trindan), or "however else you want to lay down the dop" (oc som tw wilth honom lagha mädh stikkone). ${ }^{75}$

Georgius Agricola also gives an extensive account of how to shape and polish gems at the wheel. ${ }^{76} \mathrm{He}$ explains that before gems are polished, they have to be shaped on "brass wheels" (orbi aeneo, brass is an alloy of copper, slightly harder than copper) that are sprinkled with emery: "all gems can be cut (scalpi) with emery powder, except the adamante (diamond) which can only be cut with adamantino (diamond powder) brought from India by the Lusitanians." Agricola continues that artisans usually give an "angular shape" (angulatam figuram) "to certain massive gems" (crassis quibusdam gemmis) and that gems are shaped further according to their crystal structure:

[...] although the hexagonal smaragdus, carbunculus, cyano and even the adamanti have natural faces, their translucency is enhanced (magis transluceant) by cutting new facets on them (ut aliqua parte adempta). The dull color of the hexagonal beryllo of India is enlivened by the reflections of the angles (repercussum angulorum). Many facets (plures angulos) are added to European crystallo and jaspidi in order to make them more becoming as ornaments. ${ }^{77}$

The art of faceting that Agricola describes here allowed light to be reflected from within the stone as well. A mid-sixteenth-century pendant 


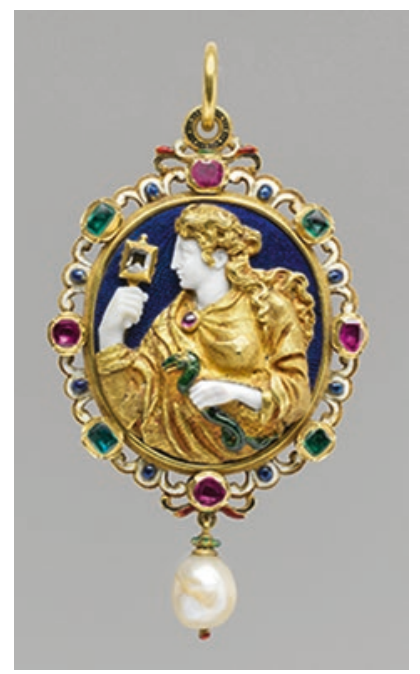

Fig. 9.6 Pendant depicting prudence gazing into a mirror while holding a snake, ca. 1550-1560 (enamelled back: nineteenth century), French, Paris (made), Carved chalcedony mounted in gold with enamel, rubies, emeralds, diamond, and pearl, $8.2 \times 4.8 \mathrm{~cm}$ (with pendant pearl). Metropolitan Museum of Art, New York, inventory number 17.190 .907

shows a beautiful example of how, through the creation of geometrically arranged, flat surfaces, gems interacted with light in an entirely new manner (Fig. 9.6). The pendant is made from a carved chalcedony (using a technique of high relief engraving, known as "cameo") representing Prudence, one of the cardinal virtues. Prudence gazes into a mirror represented by the sparkle of a faceted diamond. The scene is framed by four faceted rubies (red variety of corundum, Mohs 9) and four faceted emeralds (green variety of beryl, Mohs 7.5-8).

Like earlier treatises, Månsson and Agricola advise the lapidary to replace his disks between the smoothing stage and the polishing stage. Agricola recommends a lead disk for polishing, while Månsson recommends one made from the similarly soft tin (Mohs 1.5-1.8), but both explain that as your polishing agent, you have to use a piece of tripoli that you hold against the rotating disk while pouring water on it. Månsson additionally warns against using tripoli and emery on the same disk because they do not tolerate one another. Agricola ends his polishing instructions with the remark that to give the gem an even "higher polish" (magis expo- 
liat), it is held tightly against a wooden wheel that is covered with the hide of alcis (elk) or an equally thick skin. For this last step, which is not included in the treatise of Månsson, Agricola mentions no additional polishing agent. ${ }^{78}$

\section{Conclusion}

The comparative study of the various late medieval and early modern sources that discuss the practice of polishing provides us with a surprisingly detailed window into the history of the art of the lapidary. Not one single source can be considered complete, or best reflecting a certain artisanal "reality," but, studied together, they reveal a continuous tradition of the art lapidary in which similar methods and materials are used and explored for centuries. The late medieval sources disclose an abundance of information about the materials and processes used to work precious stones of varying hardness on flat, smooth, fixed plates. We learn about the relative hardness of stones in relation to the different kinds of abrasives and surfaces used to smooth gems; about the different steps in the polishing process; about grinding methods, that is, making small particles for use as an abrasive; and about levigation, that is, creating an even finer abrasive by separating the smaller particles from the coarser ones. The early modern sources, on the other hand, detail the advent of rotary technologies - initially for the drilling, sawing, and the polishing of engraved stones with styli, and, eventually, with brushes made from hog's hair and tripoli, a polishing agent not mentioned in the earlier treatises. The sources also suggest that only with the introduction of continuous rotary motion in the course of the fifteenth century, wheel technologies came to be used for the shaping and engraving of precious stones and for the polishing of precious stones without engravings. The speed of continuous rotary motion enabled the lapidary to work his precious stones, especially the hardest, in an entirely new manner. High-speed working not only brought out the colour and clarity of the hardest of precious stones, but it also allowed these gems to be facetted, thereby enhancing their natural crystalline shape and displaying their "brilliance." The most brilliant stone of all was the one stone that could not be polished by any of the methods used before: the diamond. And so, as Agricola tells us:

[...] the old method of polishing gems on Naxian or Armenian whetstones has been changed (vetus ratiogemmarum poliendarum cote Naxia vel Armenia est immutata) ${ }^{79}$ 


\section{Notes}

1. Georgius Agricola, De Natura Fossilium = Textbook of Mineralogy. Georgius Agricola. Translated from the First Latin Edition of 1546, ed. and trans. Mark Chance Bandy and Jean A. Bandy, The Geological Society of America Special Paper 63 (New York: The Geological Society of America, 1955), 114. For the Latin text I refer to Georgius Agricola, Georgii Agricolae De ortu o causis subterraneorum Lib. V: De natura eorum quae efflumnt ex terra Lib. IIII: De natura fossilium Lib. X: De veteribus os novis metallis Lib. II: Bermannus, sive, De re metallica dialogus: Interpretatio germanica nocum rei metallicae: addito Indice foecundissimo (Basel: H. Frobenium and N. Episcopium, 1546), 273.

2. For a recent study about the possible earliest introduction date of the wheel in ancient Mesopotamia, see Margaret Sax, Nigel D. Meeks and Dominique Collon, "The Introduction of the Lapidary Engraving Wheel in Mesopotamia," Antiquity 74, no. 284 (2000): 380-87, and for the history of working the diamond see Herbert Tillander, Diamond Cuts in Historic Jewellery: 1381-1910 (London: Art Books International, 1995); Godehard Lenzen, The History of Diamond Production and the Diamond Trade (orig. Title Produktions- und Handelsgeschichte des Diamanten), trans. F. Bradly (London: Barrie and Jenkins, 1970; first German edition, Berlin: Duncker \& Humblot, 1966), 68-81, and Paul Grodzinski, "The History of Diamond Polishing," Industrial Diamond Review l (1953): 1-13.

3. Marjolijn Bol, "Coloring Topaz, Crystal and Moonstone: Gems and the Imitation of Art and Nature, 300-1500," in Fakes!?: Hoaxes, Counterfeits and Deception in Early Modern Science, eds. Marco Beretta and Maria Conforti (Sagamore Beach: Science History Publications, 2014), 108-12.

4. The information in the following two paragraphs is loosely based on the excellent introduction to the nature and working of precious stones by the German mineralogist Max Bauer (1844-1917). The English translation of Edelsteinkunde (1896) was reprinted in 1968 because its contents were still found relevant at this time. The 1968 edition also includes an addendum by Edward Olsen to update some of Bauer's more outdated insights, see Max Bauer, Precious Stones (orig. Title Edelsteinkunde), ed. and trans. L.J. Spencer, 2 vols. (New York: Dover Publications, 1968 (first publ. 1904); first German edition, Leipzig: Chr. Herm. Tauchnitz, 1896), vol. 1, especially pages 26-59 and pages $70-87$.

5. In the English translation of Bauer's treatise, these steps are called "rounding" (to give the stone its basic form), "grinding" (to give the stone its final form), and "polishing" (to make the stone as smooth as possible). The entire process is called "cutting," see Bauer, ed. Olsen, Precious Stones, vol. 1, 79-85.

6. Ibid., 29-33.

7. Lance Grande, Allison Augustyn and John Weinstein, Gems and Gemstones: Timeless Natural Beauty of the Mineral World (Chicago: University of Chicago Press, 2009), 18. 
8. An example is the Knoop scale of hardness; see, for instance, George E. Harlow, The Nature of Diamonds (Cambridge: Cambridge University Press, 1998), 10-12.

9. Grande et al., Gems and Gemstones, 16.

10. For this reason, I cite the original Latin or vernacular term and suggest the possible mineral variety that may have been implied together with its Mohs hardness between brackets (...). If an approximation of the mineral variety cannot be established I will indicate this with a question mark (?).

11. The oldest polishing recipes can be found in the Codex Lucensis 490, which is kept in the Biblioteca Capitolare Feliniàna in Lucca, Italy. This manuscript, known as the Compositiones ad tingenda musiva or Compositiones variae, dates to the late eighth or early ninth century and contains various recipes for making pigments, metallurgy, gilding, mosaics, the dyeing of textiles and some remarks about the art of the lapidary. For a recent discussion on the Compositiones variae and the Mappae clavicula originating from two seperate traditions (the first craft and the second alchemical), see: Guido Frison and Giulia Brun, "Compositiones Lucenses and Mappae Clavicula: Two Traditions or One? New Evidence from Empirical Analysis and Assessment of the Literature," Heritage Science, 6, no. 24 (2018): 1-17.

12. The earliest surviving manuscript bearing the title Mappae clavicula is of the tenth century and now kept in the Humanist Library of Sélestat, France (Sélestat MS 17). Its recipes must have been compiled at least a century earlier, as a now lost manuscript was listed in the 821-22 library catalogue of the Benedectine monastery at Reichenau, see: Rozelle P. Johnson, "Notes on Some Manuscripts of the Mappae Clavicula," Speculum (1935), 72. The twelfth-century manuscript containing the Mappae Clavicula kept in the Corning Museum of Glass has been digitized: M29 (Manuscript of the Mappae Clavicula), Rakow Research Library, Library of the Corning Museum of Glass, Corning (06-07-2017): https://www.cmog.org/ library/manuscript-mappae-clavicula. For the English translation of the polishing recipe that can be found in this manuscript, see Cyril Stanley Smith and John G. Hawthorne. "Mappae Clavicula: A Little Key to the World of Medieval Techniques", Transactions of the American Philosophical Society 64, no. 4 (1974), [146B-E], and see also the table of concordances on pages 9-10. Smith and Hawthorne have split this long recipe into eight different sections running from $\mathrm{A}$ to $\mathrm{H}$. Please note that as multiple recipes appear on any given page in the editions cited, I refer to the numbers assigned to specific recipes in these editions by putting them between square brackets $[\ldots]$.

13. To compare a representative selection of the manuscripts containing the treatise of Theophilus and the different critical editions of the Schedula, see: "The Schedula Diversarum Artium - a Digital Critical Edition," http://schedula.uni-koeln.de/, accessed 6 July 2017. 
14. London, British Library, Harley 3915, ff. 107r-109v. For Dodwell's remarks about this manuscript, see Theophilus, The Various Arts: De Diversis Artibus, ed. and trans. Charles Reginald Dodwell (London: Thomas Nelson, 1961), lxiii-lxvi.

15. Bauer, ed. Olsen, Precious Stones, vol. 1, 80.

16. "Mappae clavicula," ed. Smith and Hawthorne, [146B-E]; "Mappae clavicula," transcr. Philipps, [146].

17. Theophilus, ed. Dodwell, The Various Arts, [LIX]. The recipe in question is part of a larger series of instructions on making sculpted metal in low relief.

18. Ibid., [LIX].

19. Bauer testifies to the continuity of this practice when he recommends that when a gem of comparatively little value is worked, a dop made from wood or metal can be used against which the gemstone is glued with a cement made from "pitch, resin, or shellac, and the finest brick-dust" (for costly gems, another type of dop is used). Bauer, ed. Olsen, Precious Stones, vol. 1,80 .

20. Theophilus, ed. Dodwell, The Various Arts, [XCV]: [...] hoc modo limatur et politur.

21. Sometimes the sources also refer to the entire process of bringing a gem to smoothness with the term fricanto ("to rub").

22. Theophilus, ed. Dodwell, The Various Arts, [XCV].

23. Bauer, ed. Olsen, Precious Stones, vol. 1, 80.

24. "Mappae clavicula," ed. Smith and Hawthorne, [146-C]; "Mappae clavicula," transcr., Philipps, [146]. The treatise does mention that glass can be shaped by rubbing it on sandstone, compare recipe $146-\mathrm{D}$ in table 1 .

25. For a recent Italian edition of the treatise of Eraclius, see I colori e le arti dei Romani e la compilazione pseudo-Eracliana, ed. and trans. Chiara Garzya Romano (Naples: Il Mulino, 1996). Romano considers Books I and II to be eighth century and of Italian origin and argues that Book III dates to the twelfth or thirteenth century and is of French or English origin. Here, I refer to Merrifield's edition, using her English translation: Original Treatises Dating from the XIIth to XVIIIth Centuries on the Arts of Painting, ed. and trans. Mary Philadelphia Merrifield, 2 vols. (London: John Murray, 1849), vol. 1, 166-7. The manuscript of Eraclius in the British Library has also been published by Rudolph Erich Raspe, A critical essay on oil-painting: proving that the art of painting in oil was known before the pretended discovery of John and Hubert van Eyck; to which are added, Theophilus De arte pigendi, Eraclius De artibus Romanorum, and a review of Farinator's Lumen animae (London, 1781).

26. The third book of Eraclius also includes a recipe for the polishing of haematite (Mohs 5.5-6.5) that is not discussed in the text here, but which is 
included in Table 1, see: Eraclius, De coloribus et artibus Romanorum, Book 3, ed. Merrifield, vol. 1, [XII].

27. Ibid., [XII]: Sed nec duritiem poteris praerumpere tantam; Mollitie plumbi, nisi quaedam junxeris illi; Tanquam pulverulas fornacis fragmine micas; Quae tenerae poteris laminae connectere plumbi; Haec etenim plumbum conjunctio reddet acutum. At quum rursus habent lateris fragmenta vigorem; Concidi adjuncta paulatim fluminis unda; Sed vim cristalli cruor antea temperet hirci.

28. Theophilus, ed. Dodwell, The Various Arts, [XCV].

29. "Mappae clavicula," ed. Smith and Hawthorne, [146-C]; "Mappae clavicula," transcr., Philipps, [146]. Theophilus did not include amethistus but additionally listed calcedonius with the softer gems.

30. Eraclius, De coloribus et artibus Romanorum, Book 1, ed. Merrifield, vol. $1,[\mathrm{X}]$. For the influence of mineral hardness on a gem's ability to take on a polish, see also the second paragraph of this chapter.

31. Theophilus, ed. Dodwell, The Various Arts, [XCV].

32. "Mappae clavicula," ed. Smith and Hawthorne, [146-B]; "Mappae clavicula," transcr. Philipps, [146].

33. Ibid., [133] and Ibid., [133]. The entry to emery can also be found in the two earlier related manuscripts; not for the polishing of precious stones, however, but for the rubbing of mosaic, see Compositiones ad tingenda musiva, ed. Hedfors, [A30-B16, B8-12 and B12-15]. Theophilus similarly uses the term limo to describe the practice of "filing".

34. "Mappae clavicula," ed. Smith and Hawthorne, [146-E]; "Mappae clavicula," transcr. Philips, [146].

35. Theophilus, ed. Dodwell, The Various Arts, [XCV].

36. Strangely, the Mappae clavicula also mentions that calcined pyrite on copper is used for polishing the softer gems, while the recipe for polishing the jacynctus explains that "other hard gems" can be polished with the ground up sherds of ancient pots (fragmento testeo, quod fit ex vasis antiquis) or aut pulverefacto de cimolia (powder from cimolian earth, variety of soft clay). It is quite likely that, due to a copyist's error, the abrasives for the harder and softer gems were switched here. See also Table 1.

37. Geoffroy Grassin, "Le travail des gemmes au xiiie siècle dans La doctrina poliendi pretiosos lapides," Cabiers de civilisation médiévale 42, no. 166 (1999): 111-12.

38. Grassin, "Le travail des gemmes," 113 [I].

39. Grassin attempted to identify the different stones mentioned in the doctrina; I have used his suggestions here, see "Le travail des gemmes," 120-22.

40. Ibid., $113[\mathrm{~V}]$.

41. Ibid., 113 [VI]. 
42. Ibid., 113 [VIII].

43. Ibid., 113 [VII].

44. As we have seen, the Mappae clavicula also pointed out that pyrite was calcined. In another recipe not discussed in the main text here (see, Table 1), it also mentions pounded, calcined pebbles, and calcined rock crystal, both applied to leather stretched on a plate, see "Mappae clavicula," ed. Smith and Hawthorne, [191-A].

45. Grassin, "Le travail des gemmes," 113 [VII].

46. Lara Broecke, Cennino Cennini's Il Libro dell'Arte: A New English Translation and Commentary with Italian Transcription (London: Archetype, 2015), [XXXVI]. In book two of his treatise on glass painting, Theophilus too mentions porphyry stone for grinding glass. It is used, among other things, to grind glass fine enough to be able to paint with it on glass objects, compare Theophilus, ed. Dodwell, The Various Arts, [XIII, XIV, XIX and XXX].

47. Theophilus, for instance, mentions wheels for turning heavy bell-ores and a pewterer's lathe that "it is set up the same way as the one on which platters and other wooden vessels are turned". He also discusses the use of a bow-driven drill for the piercing of pearls, and, surprisingly, even a lathe for the polishing of bone knobs for the use on bishop's croziers (Table 2) in the two recipes directly preceding and succeeding the recipe on the polishing of precious stones. Compare Theophilus, ed. Dodwell, The Various Arts, [LXXXV], [LXXXVIII], [XCIV] and [XCVI].

48. Grassin, "Le travail des gemmes," 114 [XI].

49. Compare with Theophilus' manual method for piercing a crystal, see recipe XCV in Table 1.

50. Grassin, "Le travail des gemmes," 113 [III, IV].

51. Grassin, "Le travail des gemmes," 113 [III].

52. Ibid., 114 [IX].

53. Ibid., $114[\mathrm{X}]$.

54. Even though the term carbunculus could refer to a variety of red translucent stones, Agricola's remark about its hexagonal crystal structure suggests that he may refer to a red variety of corundum in this case. See also the passage on faceting from Agricola's De natura fossilium cited later in this chapter.

55. Agricola, ed. Bandy and Bandy, Textbook of Mineralogy, 114; Agricola, De natura fossilium Lib. X, book VI, 273.

56. Ibid. With this last observation, Agricola echoes a remark by Albertus Magnus (see, De mineralibus, ca. 1265) who considers it wasteful to use such an expensive tool for engraving gems of little value and even questions whether a diamond point can be used to engrave. Before the art of engraving was made popular again since ancient times, only relatively 
cheap and soft gems, such as rock crystal, amethyst, or even glass imitations of precious stones were carved with images. Such practices may have led Albertus Magnus to wonder why anyone would or could use a tool as costly as the diamond to engrave comparatively cheap materials. See Albertus Magnus, Book of Minerals, ed. and trans. Dorothy Wyckoff (Oxford: Clarendon Press, 1967), 133.

57. For the German translation of Månsson's manuscripts, see Peder Månsson, Peder Månssons Schriften über technische Chemie und Hüttenwesen, ed. and trans. Otto Johannsen (Berlin: VDI-Verlag GMBH, 1941) and for the Swedish transcription of the original manuscripts, see Peder Månsson, Peder Månssons skrifter på svenska, ed. Robert Geete (Stockholm: P. A. Norstedt \& Söner, 1913-1915), 499-530.

58. Månsson, ed. Johannsen, Peder Månssons Schriften, 7.

59. For the full list, which also includes Latin treatises by Albertus Magnus, selections from Pliny, various texts on alchemy, a treatise by Thomas of Aquino, and so on, I refer to Månsson, ed. Johannsen, Peder Månssons Schriften, 14-19.

60. Ibid., 18.

61. Månsson lived in Italy between $1508-1524$ and there is also some internal evidence in Månsson's text that the original manuscript may have been composed there. See, Ibid., $1-10$ and 18.

62. Two of these machines have been translated to modern technical drawings by Otto Johannsen, see Ibid., 143 and 147.

63. Woodbury, Studies in the History of Machine Tools, 38-50.

64. Månsson, ed. Johannsen, Peder Månssons Schriften, 140-1 and Månsson, ed. Geete, Peder Månssons Skrifter, 504-7 [4].

65. Ibid., 148. In the nineteenth century, Bauer mentions these disks, now made from iron, for the art of engraving as well, see Bauer, ed. Olsen, Precious Stones, vol. 1,88-7 (Bauer's smallest disk is about $2 \mathrm{~mm}$ ).

66. Ibid., 148-9.

67. An., Ms. Français 640, Bibliothèque nationale de France, Paris. The Making and Knowing Project, directed by Pamela Smith, is currently working towards an open-access digital edition and translation of this intriguing collection of recipes, see: "The Making and Knowing Project: Intersections of Craft Making and Scientific Knowing," Columbia University, New York (06-07-2017): http://www.makingandknowing.org/. The manuscript has been digitized and can be accessed here: Département des manuscrits, Bibliothèque nationale de France, Paris (06-07-2017): http://gallica.bnf. fr/ark:/12148/btvlbl050000lg.r=.langENr.

68. Bnf. Ms. Fr. $640,11 v$.

69. Ibid., 013r. Tripoli is not mentioned as a polishing agent in late medieval sources, but is often mentioned in early modern sources that discuss the art of the lapidary. 
70. I discuss this further in the next paragraph.

71. Compare also an., "Bnf. Ms. Fr. 640," 012v and 13r for the rather mysterious recipe Pour blanchir enilanroc ("to whiten enilanroc", carnelian spelled backwards in French). The author of Ms. Fr. 640 writes that he experimented with a layer of ground arsenic on marble, which he could then engrave with a diamond point like a piece of agate (which was used for making cameos). He polished his engraved carnelian imitation with hog bristles and tripoli.

72. Månsson, ed. Johannsen, Peder Månssons Schriften, 149-150 and Månsson, ed. Geete, Peder Månssons Skrifter, 512-13 [5].

73. Månsson specifies that the stylus has to be "without disk" as these, as we have seen, are used for the engraving of precious stones.

74. In the case of an intaglio, the image is sunk into the stone and lies below its surface. A cameo shows its engraved image as if raised above the surface of the stone. Both types of engravings were popular and can be made on the same machine.

75. Månsson, ed. Johannsen, Peder Månssons Schriften, 141-3 and Månsson, ed. Geete, Peder Månssons Skrifter, 506 [4].

76. Agricola, ed. Bandy and Bandy, Textbook of Mineralogy, 114; Agricola, De natura fossilium Lib. X, book VI, 273-4.

77. Ibid.

78. In earlier treatises, as we have seen, leather was often used with tile rubbings or another soft polishing agent.

79. Agricola, ed. Bandy and Bandy, Textbook of Mineralogy,114; Agricola, De natura fossilium Lib. X, book VI, 273.

\section{BIBLIOGRAPHY}

Agricola, Georgius. Georgii Agricolae De ortu \& causis subterraneorum Lib. V: De natura eorum quae efflunnt ex terra Lib. IIII: De natura fossilium Lib. X: De veteribus o novis metallis Lib. II: Bermannus, sive, De re metallica dialogus: Interpretatio germanica nocum rei metallicae: addito Indice foecundissimo. Basel: H. Frobenium and N. Episcopium, 1546.

- De Natura Fossilium = Textbook of Mineralogy. Georgius Agricola . Translated from the first Latin edition of 1546. Edited and translated by Mark Chance Bandy and Jean A. Bandy. The Geological Society of America Special Paper 63. New York: The Geological Society of America, 1955.

Bauer, Max, Precious Stones (orig. title Edelsteinkunde), edited and translated by L.J. Spencer, 2 vols. New York: Dover Publications, 1968 (first publ. 1904); lst German ed. Leipzig: Chr. Herm. Tauchnitz, 1896.

Bol, Marjolijn. "Coloring Topaz, Crystal and Moonstone: Gems and the Imitation of Art and Nature, 300-1500." In Fakes!?: Hoaxes, Counterfeits and Deception 
in Early Modern Science, edited by Marco Beretta and Maria Conforti, 108129. Sagamore Beach: Science History Publications, 2014.

Cellini, Benvenuto. I trattati dell'oreficeria e della scultura di Benvenuto Cellini. Edited and translated by Carlo Milanesi. Florence: F. Le Monnier, 1857.

. The Treatises on Goldsmithing and Sculpture. Edited and translated by C. R. Ashbee. New York: Dover Publications, 1967.

Cennini, Cennino. Cennino Cennini's Il Libro dell'Arte: A New English Translation and Commentary with Italian Transcription. Edited and translated by Lara Broecke. London: Archetype, 2015.

Clarke, Mark. The Art of all Colours: Mediaeval Recipe Books for Painters and Illuminators. London: Archetype, 2001.

Eraclius. I colori e le arti dei Romani e la compilazione pseudo-eracliana. Edited and translated by Chiara Garzya Romano, Testi storici, filosofici e letterari. Napels: Il Mulino, 1996.

Frison, Guido, and Giulia Brun. Compositiones Lucenses and Mappae Clavicula: Two Traditions or One? New Evidence from Empirical Analysis and Assessment of the Literature. Heritage Science 6, no. 24 (2018): 1-17.

Grande, Lance, Augustyn, Allison and John Weinstein. Gems and Gemstones: Timeless Natural Beauty of the Mineral World. Chicago: University of Chicago Press, 2009.

Grassin, Geoffroy. "Le travail des gemmes au xiiie siècle dans La doctrina poliendi pretiosos lapides." Cahiers de civilisation médiévale 42, no. 166 (1999): 111-37.

Grodzinski, Paul. The History of Diamond Polishing. Industrial Diamond Review 1 (1953): 1-13.

Halleux, Robert. "Recettes d'artisan, recettes d'alchimiste." In Artes mechanicae en Europe médiévale: actes du colloque du 15 octobre 1987, edited by Ria JansenSieben, 25-49. Brussels: Archives et bibliothèques de Belgique, 1989.

Harlow, George E. The Nature of Diamonds. Cambridge: Cambridge University Press, 1998.

Hedfors, Hjalmar, Compositiones ad tingenda musiva [Codex Lucensis 490] Herausgeben übersetzt und philologisch erklärt (Uppsala: Almqvist \& Wiksells, 1932).

Johnson, Rozelle P. "Notes on Some Manuscripts of the Mappae Clavicula." Speculum 10, no. 1 (1935): 72-81.

Lenzen, Godehard. The History of Diamond Production and the Diamond Trade (orig. title Produktions- und Handelsgeschichte des Diamanten). Translated by F. Bradly. London: Barrie and Jenkins, 1970; 1st German edition. Berlin: Duncker \& Humblot, 1966.

Magnus, Albertus. Book of Minerals. Edited and translated by Dorothy Wyckoff. Oxford: Clarendon Press, 1967.

Månsson, Peder. Peder Månssons skrifter på svenska. Edited by Robert Geete. Stockholm: P. A. Norstedt \& Söner, 1913-1915. 
Peder Månssons Schriften über technische Chemie und Hüttenwesen. Edited and translated by Otto Johannsen. Berlin: VDI-Verlag GMBH, 1941.

Merrifield, Mary Philadelphia. Original Treatises Dating from the XIIth to XVIIIth Centuries on the Arts of Painting, 2 vols. London: John Murray, 1849.

Philipps, Thomas. "Letter from Sir Thomas Phillipps, Bart. F.r.s., F.s.a., Addressed to Albert Way, Esq., Director, Communicating a Transcript of a Ms. Treatise on the Preparation of Pigments, and on Various Processes of the Decorative Arts Practiced During the Middle Ages, Written in the Twelfth Century, and Entitled Mappae Clavicula." In Archaeologia, or, Miscellaneous Tracts Relating to Antiquity, 183-244. London: Society of Antiquaries of London, 1770.

Raspe, Rudolph Erich. A Critical Essay on Oil-painting. London: H. Goldney, 1781.

Sax, Margaret, Nigel D. Meeks, and Dominique Collon. "The Introduction of the Lapidary Engraving Wheel in Mesopotamia." Antiquity 74, no. 284 (2000): 380-87.

Smith, Cyril Stanley, and John G. Hawthorne. "Mappae Clavicula: A Little Key to the World of Medieval Techniques." Transactions of the American Philosophical Society 64, no. 4 (1974): 1-128.

Theophilus. The Various Arts: De Diversis Artibus. Edited and translated by Charles Reginald Dodwell. London: Thomas Nelson, 1961.

Tillander, Herbert, Diamond Cuts in Historic Jewellery: 1381-1910. London: Art Books International, 1995.

Woodbury, Robert S. Studies in the History of Machine Tools. Cambridge, MA: MIT Press, 1972.

OnLine Resources

M29 (Manuscript of the Mappae Clavicula), Rakow Research Library, Library of the Corning Museum of Glass, Corning, N.Y. Accessed July 6, 2017. https:// www.cmog.org/library/manuscript-mappae-clavicula.

Ms. Français 640, Département des manuscrits, Bibliothèque nationale de France, Paris. Accessed July 6, 2017, http://gallica.bnf.fr/ark:/12148/btvlb10500 001 g.r $=$.langENr.

The Making and Knowing Project: Intersections of Craft Making and Scientific Knowing. Columbia University, New York. Accessed July 6, 2017, http:// www.makingandknowing.org.

The Schedula Diversarum Artium-A Digital Critical Edition. Thomas-Institute of the University of Cologne. Accessed July 6, 2017, http://schedula.unikoeln.de. 